Research paper

\title{
How to convert digital offerings into revenue enhancement - Conceptualizing business model dynamics through explorative case studies
}

\author{
Heiko Gebauer $^{\mathrm{a}, \mathrm{b}, \mathrm{d},{ }^{*}, \text { Alexander Arzt }}{ }^{\mathrm{b}}$, Marko Kohtamäki ${ }^{\mathrm{c}}$, Claudio Lamprecht ${ }^{\mathrm{d}}$, Vinit Parida ${ }^{\mathrm{e}}$, \\ Lars Witell $^{\mathrm{a}}$, Felix Wortmann ${ }^{\mathrm{d}}$ \\ ${ }^{a}$ Department of Management and Engineering, Linköping University, SE-581 83 Linköping, Sweden \\ ${ }^{\mathrm{b}}$ Fraunhofer IMW, Neumarkt 7-10, 04109 Leipzig, Germany \\ ${ }^{\mathrm{c}}$ University of Vaasa, Wolffintie 34, 65200 Vaasa, Finland \\ ${ }^{d}$ ITEM-HSG, Bosch IoT Lab, University of St.Gallen, Dufourstrasse 40a, 9000 St.Gallen, Switzerland \\ e Technical University Lulea, A3211 Luleå, Sweden
}

\section{A R T I C L E I N F O}

\section{Keywords:}

Digitalization

Digital offerings

Business models

Business model innovations

Competitive advantages

Business model components

Revenue enhancement

Value creation

\begin{abstract}
A B S T R A C T
Equipment manufacturers are currently utilizing new digital technologies such as the Internet of Things (IoT), Artificial Intelligence, or Big Data, for new digital offerings. However, these offerings seldom enhance revenue, because companies struggle with business model (BM) dynamics. By analyzing 27 companies through an explorative case-study approach, the authors consider how companies can successfully achieve revenue enhancement through digital offerings. The result is a threefold framework for revenue enhancement through digital offerings. First, this framework distinguishes between three phases of BM dynamics: 1) augmenting products through a "hardware plus" logic, 2) developing a portfolio of multiple logics for creating customer value, 3) integrating this portfolio through platform logic. Second, the framework emphasizes that three barriers, which we refer to as confidence, mixing, and collaboration barrier, limit the progress from Phases 1 to 3 . Third, the framework reveals that each phase contains certain modifications of BM components. In the first phase, companies adapt their BM components slightly, so as to advance toward a "hardware plus" logic. In the second phase, companies embrace more radical BM innovations in order to convert services into an outcome-based BM and develop a new software subscription BM. In the third phase, companies modify BM components in order to integrate the BMs internally and to open them up for external collaboration partners.
\end{abstract}

\section{Introduction}

Equipment manufacturers no longer provide only combinations of traditional products and services to their customers. They also invest in digital technologies to make their products and services "smart". They embed sensors, actuators, software etc. into their products and utilize product connectivity, so as to collect data on product conditions, performance and usage. The data is analyzed in such a way that equipment manufacturers can improve customer efficiency and effectiveness. The use of digital technology by equipment manufacturers is often referred to in such terms as the (industrial) Internet of Things, Artificial Intelligence, Big Data, Industry 4.0, or digitalization (Hecker, Döbel, Rüping, \& Schmitz, 2017; Lee, 2017; Ng \& Wakenshaw, 2017; Opresnik \& Taisch, 2015). Digital technologies allow equipment manufacturers to extend their traditional product and service offerings through digital ones in order to add customer value.

Baker Hughes, an equipment manufacturer for the oil and gas industry, is a good example of such a digital extension. Besides traditional equipment and services, Baker Hughes promotes AI through digital offerings ranging from identifying and preventing anomalies in equipment operations, to reducing energy consumption, as well as prioritizing and optimizing equipment maintenance and planning. In 2018, traditional product and service offerings generated revenue of 20.3 billion USD. In addition, digital offerings generated another 2.6 billion USD (GE, 2018).

While such anecdotal evidence supports the notion of revenue enhancement through digital offerings, in business practice, such enhancements remain modest (e.g., BCG, 2016; Downes \& Nunes, 2013; Iansiti \& Lakhani, 2014). There is anecdotal evidence of companies

\footnotetext{
* Corresponding author.

E-mail addresses: heiko.gebauer@liu.se (H. Gebauer), alexander.arzt@imw.fraunhofer.de (A. Arzt), marko.kohtamaki@uwasa.fi (M. Kohtamäki), claudio. lamprecht@unisg.ch (C. Lamprecht), vinit.parida@ltu.se (V. Parida), lars.witell@liu.se (L. Witell), felix.wortmann@unisg.ch (F. Wortmann).
} 
facing a so-called digitalization paradox (in short: digital paradox), which means that they invest in digital offerings, but struggle to achieve the expected revenue growth, despite the proven growth potential of digital technologies (Gebauer, Fleisch, Lamprecht, \& Wortmann, 2020; Kohtamäki, Parida, Patel, \& Gebauer, 2020; Wortmann, Bilgeri, Gebauer, Lamprecht, \& Fleisch, 2019). Obstacles in managing BM dynamics could be a reason for the digital paradox. There are various frameworks describing obstacles in BM dynamics (e.g. Baden-Fuller \& Mangematin, 2013; Berends, Smits, Reymen, \& Podoynitsyna, 2016; Cavalcante, Kesting, \& Ulhøi, 2011; Morris, Schindehutte, \& Allen, 2005). The obstacles that might explain the digital paradox include: a) companies failing to progress along the right sequence of phases for changing the overall business logic, b) companies not overcoming barriers to management cognition, and c) companies not being able to consistently modify the key BM components (value proposition, value creation and profit equation).

The aim of this article is to explore how equipment-manufacturing companies achieve revenue enhancement through digital offerings. Our research questions are: What phases do companies go through on their way to achieving revenue enhancement through digital offerings? How do companies modify BM components in each phase? What barriers limit progress along the various phases and hinder companies from advancing to the next phase?

In order to address these research questions, we apply existing frameworks of BM dynamics to digital offerings in the equipmentmanufacturing context. We start by exploring the distinct phases that change the overall business logic. We then describe barriers that might limit the progress along these phases. Thirdly, we explain key modifications in the BM components of each phase. Fourthly and finally, we integrate these contributions into a framework that describes BM dynamics for converting digital offerings into revenue enhancement.

\section{A theoretical overview of servitization and business models}

\subsection{Equipment manufacturers: from physical to digital offerings}

The business logic of equipment manufacturers is about combining products and services into customer solutions that make customers more successful by increasing their efficiency and effectiveness (Tuli, Kohli, \& Bharadwaj, 2007). Products refer to machines and spare parts. Services refer to basic ones such as financial and field services (e.g. repair, maintenance), as well as more advanced services such as equipment modernization, integration, and optimization (Baines et al., 2017), as well as services for guaranteeing and charging for product usage and performance (e.g. pay-per-use services) (Cusumano, Kahl, \& Suarez, 2015). Thus, value creation includes activities for developing, manufacturing, and selling products, providing services, and integrating them into customer-specific solutions. As for the profit equation, both products and services contribute to revenue, with services accounting for $20 \%$ to $50 \%$ of total revenue (Fischer, Gebauer, \& Fleisch, 2012).

Equipment manufacturers have recently been investing in making their product and service offerings "smart", by connecting equipment with the internet and enabling data exchange with customers. They embed software, sensors, actuators, and microprocessors into their products, and add connectivity components (ports, antennae, protocols, and networks) to enable communication between the product and the data cloud (Fleisch, Weinberger, \& Wortmann, 2015; Ng \& Wakenshaw, 2017; Yoo, Boland Jr, Lyytinen, \& Majchrzak, 2012). This data cloud leads to a new technology stack of basic and advanced data analytics through big data, machine learning, and artificial intelligence (Opresnik \& Taisch, 2015). Scholars refer to the use of digital technologies for developing new services and improving existing ones, as digital servitization. Companies utilize digital technologies to create new business models, to facilitate novel ways of (co)creating value and to generate valuable knowledge from data (Paschou, Rapaccini, Adrodegari, \& Saccani, 2020).
Fig. 1 depicts the basic idea of making the offering smart and connected. On the left, Fig. 1 shows the explained structure. In the center, a simple growth matrix shows the revenue-enhancement potential. On the right, there is a company example of revenue distribution and expected revenue enhancement. (See Table 1.)

In the growth matrix, the horizontal axis distinguishes between product and service revenue, whereas the vertical axis depicts the revenue generated through physical and digital offerings. Moving along the horizontal axis suggests that companies increasingly generate revenue from classic services, whereas moving up the vertical axis implies revenue enhancement through digital offerings (Gebauer et al., 2020). These offerings include digital products such as on-premises software or digital services. As in the example of Baker Hughes, digital offerings include advanced services, which increasingly take advantage of digital technologies, and include software applications sold as a service. The company example (see Fig. 1) shows a typical revenue structure, with $75.8 \%$ being generated through products and $22.7 \%$ through classic services. In addition, $6.5 \%$ of revenue derives from software offerings and $1.5 \%$ from digital services. Annual growth rates for revenue were observed to be $1-2 \%$ for products, $2-4 \%$ for classic services, $8 \%$ for digital products, and $15 \%$ for digital services. This means that revenue enhancements through digital offerings are expected to achieve the highest growth rates.

These revenue enhancements are the results of converting digital technologies into new digital offerings. Accordingly, such enhancements are a likely outcome of valid reasoning about the growth potential of digital technologies. However, despite such reasoning, there is evidence of companies struggling to earn the expected revenue growth. For example, one company expected to generate about $15 \%$ of its revenue through digital services over the next five years, but could only achieve about 5\%. Another company reported earning around 500 million Euros through physical products and services. The company invested about 7 million Euros in the connectivity of its products, and employs a specialized team to collect and analyze the data, maintain connectivity, and promote and deliver new digital offerings. This team costs nearly 1 million Euros every year. Despite such annual outlays, the company could still not enhance its revenue through digital offerings.

Such anecdotal evidence seems to contradict the basic premise and confirm the abovementioned digital paradox (Gebauer et al., 2020; Wortmann et al., 2019). This means that companies invest in digital offerings, but fail to enhance revenue accordingly and sufficiently. A possible reason for the digital paradox could be that companies fail to cope with the obstacles that digital offerings might trigger in the BM dynamics (e.g. sequence of phases in the BM dynamics, management cognition, and modifications in the BM components - value proposition, value creation, and profit equation).

\subsection{BM concept}

In general, the BM concept can be described as a complex system hypothetically enabling the core value proposition to be transferred to the customer as a benefit (Seelos \& Mair, 2007). The BM concept straddles two intertwined perspectives, a holistic one based on the logic that underlies the business, and a multi-component perspective through which the overall business logic is implemented (Zott \& Amit, 2013). From the holistic perspective, BMs are "templates" for the way companies conduct their business (Zott \& Amit, 2013). Accordingly, BMs are regarded as overall theories of doing business and/or as typical models that can change "in the minds of managers" (Baden-Fuller \& Morgan, 2010; Chesbrough \& Rosenbloom, 2002; McKendrick \& Carroll, 2001).

From the multiple-component perspective, BMs are a particular configuration that link the internal operations of a firm with the customer value proposition in the external market environment and how value is monetized (Baden-Fuller \& Mangematin, 2013; DaSilva \& Trkman, 2014). Although there are several conceptualizations of BM components (Osterwalder \& Pigneur, 2010; Wirtz, Pistoia, Ullrich, \& 


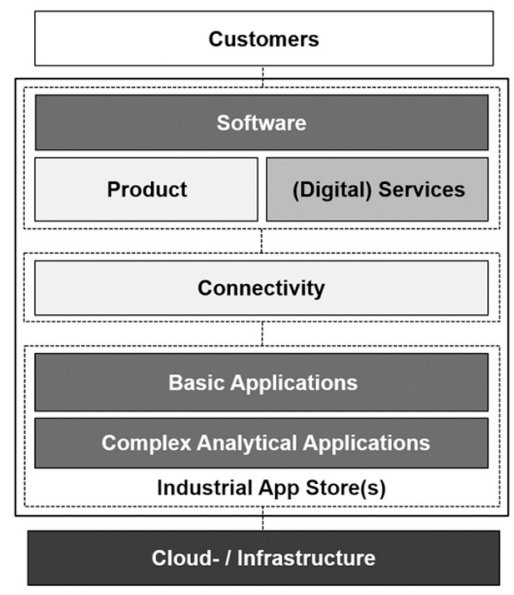

${ }^{1}$ based on Porter \& Heppelmann, 2015
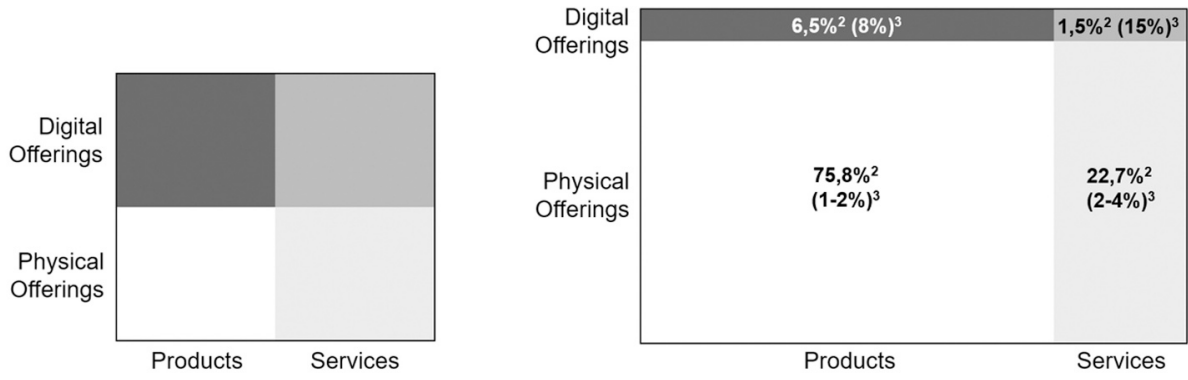

2 percentage of revenue

${ }^{3}$ expected compound annual growth rate

Fig. 1. The role of digital offerings for an equipment manufacturer.

Table 1

Overview of digital offerings from a static perspective.

\begin{tabular}{|c|c|c|c|}
\hline Offering & Description & Subtype & Description \\
\hline \multirow[t]{2}{*}{$\begin{array}{l}\text { Digital } \\
\text { features }\end{array}$} & $\begin{array}{l}\text { Expanding hardware } \\
\text { capabilities through } \\
\text { digital features }\end{array}$ & $\begin{array}{l}\text { Integrated } \\
\text { unlockable } \\
\text { features }\end{array}$ & $\begin{array}{l}\text { Offering unlockable } \\
\text { hardware features }\end{array}$ \\
\hline & $\begin{array}{l}\text { ("hardware plus" } \\
\text { logic) }\end{array}$ & Digital add-ons & $\begin{array}{l}\text { Offering capability } \\
\text { expansion through } \\
\text { digital add-ons }\end{array}$ \\
\hline \multirow[t]{2}{*}{$\begin{array}{l}\text { Payment } \\
\text { schemes }\end{array}$} & $\begin{array}{l}\text { Offering new data- } \\
\text { driven payment } \\
\text { schemes }\end{array}$ & $\begin{array}{l}\text { Usage-based } \\
\text { (pay-per-use) }\end{array}$ & $\begin{array}{l}\text { Monitoring data to } \\
\text { charge customers } \\
\text { according to the usage } \\
\text { of an offering }\end{array}$ \\
\hline & & $\begin{array}{l}\text { Performance- } \\
\text { based (pay-for- } \\
\text { performance) }\end{array}$ & $\begin{array}{l}\text { Monitoring data to } \\
\text { charge customers } \\
\text { according to the } \\
\text { performance of an } \\
\text { offering }\end{array}$ \\
\hline \multirow[t]{3}{*}{ Software } & $\begin{array}{l}\text { Offering software tools } \\
\text { (e.g. embedded in IoT } \\
\text { platforms) for }\end{array}$ & License-based & $\begin{array}{l}\text { Selling software } \\
\text { licenses valid for a } \\
\text { fixed amount of time }\end{array}$ \\
\hline & $\begin{array}{l}\text { monitoring, } \\
\text { visualizing and } \\
\text { optimizing assets and }\end{array}$ & $\begin{array}{l}\text { Subscription- } \\
\text { based }\end{array}$ & $\begin{array}{l}\text { Charging customers } \\
\text { for software on a } \\
\text { recurring basis }\end{array}$ \\
\hline & processes & "Freemium" & $\begin{array}{l}\text { offering free } \\
\text { capabilities and fee- } \\
\text { based premium } \\
\text { features }\end{array}$ \\
\hline \multirow[t]{3}{*}{ Outcomes } & $\begin{array}{l}\text { Utilizing digital } \\
\text { technology for } \\
\text { guaranteeing }\end{array}$ & $\begin{array}{l}\text { Asset } \\
\text { availability }\end{array}$ & $\begin{array}{l}\text { Guaranteeing a } \\
\text { specific asset- } \\
\text { availability level }\end{array}$ \\
\hline & $\begin{array}{l}\text { outcomes (e.g. } \\
\text { embedded in smart } \\
\text { service contracts) }\end{array}$ & $\begin{array}{l}\text { Asset } \\
\text { performance }\end{array}$ & $\begin{array}{l}\text { Guaranteeing a } \\
\text { specific asset- } \\
\text { performance level }\end{array}$ \\
\hline & & $\begin{array}{l}\text { Customer } \\
\text { outcome }\end{array}$ & $\begin{array}{l}\text { Guaranteeing a } \\
\text { specific customer } \\
\text { outcome (e.g. increase } \\
\text { in overall equipment } \\
\text { effectiveness) }\end{array}$ \\
\hline
\end{tabular}

Göttel, 2016), the most concise one identifies three key components: value proposition, value creation (delivery), and profit equation (Ghezzi, Cortimiglia, \& Frank, 2015; Teece, 2010).

The notion of a value proposition subsumes all facets of company offerings that render value to customers (Chesbrough \& Rosenbloom, 2002), addressing particular customer needs or problems. Companies need to consider relevant customer segments and determine which communication and delivery channels can reach those segments (Osterwalder \& Pigneur, 2010). To act on their value propositions, they require certain resources, capabilities, and processes (Johnson, Christensen, \& Kagermann, 2008), known as value-creation activities (Amit \& Zott, 2001). Value creation can be managed within companies, or through collaboration with external partners (Chesbrough, 2010). The profit equation is the financial manifestation of the value proposition and the value creation mechanism; companies address how value is captured for customers and how costs for value creation are structured (Bowman \& Ambrosini, 2000). These three BM components need to be compatible with holistic business logic (Velu, 2017).

The BM concept serves two interlinked purposes, namely to provide an orientation for the development of company activities and, at the same time, the flexibility to allow for change. Accordingly, the literature has reflected on BMs from both a static and a dynamic perspective (Demil \& Lecocq, 2010). The former perspective describes certain types of BMs through highlighting different business logics and configurations of BM components, while the dynamic perspective focuses on how the $\mathrm{BM}$ evolves over time.

\subsection{A static perspective on business models}

The literature describes various strategies for companies to integrate digital offerings into their portfolio from a static perspective and focusing on particular BM elements (e.g.Benson, 2015; Bilgeri, Brandt, Lang, Tesch, \& Weinberger, 2015; Bonnet, Buvat, \& Subrahmanyam, 2014; Fleisch, Weinberger, \& Wortmann, 2014; Liozu \& Ulaga, 2018; Weinberger, Bilgeri, \& Fleisch, 2016).

Companies can follow a "hardware plus" logic to add customer value to physical products through digital features. Customers purchase or activate these features during the usage period, in order to expand product capabilities. Digital offerings such as software applications can be sold to customers through licenses, for example with different functionality-level options, valid for a fixed period of time. In this context, many companies use subscription models which charge customers on a recurring basis. In so-called freemium models, companies sell offerings with selected free digital capabilities, anticipating that some customers will upgrade to fee-based premium features. Alternatively, companies can offer customers a free trial requiring payment after a certain timeframe. Moreover, companies offer customers new payment schemes facilitated by data about asset usage and performance. Usage- 
based or pay-per-use models charge customers according to an agreedupon metric, for example, usage time. Similarly, companies can charge customers for the performance of an asset, often referred to as performance-based or pay-for-performance models. Digital offerings can also be embedded in smart service contracts in order to guarantee customers certain outcomes such as asset availability, asset performance or overall efficiency increases. Companies utilize digital platforms to address more complex customer problems by analyzing and combining data about various products in the platform ecosystem.

\subsection{A dynamic perspective on business models}

Firms must often cope with the situation that BMs, in terms of business logic and BM components, are in a permanent state of disequilibrium (Demil \& Lecocq, 2010; Dunford, Palmer, \& Benveniste, 2010; Teece, 2010). From a holistic perspective, the BM dynamics describe the discovery and adoption of a fundamentally different business logic, whereas the component perspective suggests that BM dynamics are the result of deliberate modifications of one or multiple BM components (Cavalcante et al., 2011; Markides, 2006). This is about redefining the current offering, and how it is provided to customers, which includes searching for new ways to propose value to the customer, to create and capture value (Casadesus-Masanell \& Zhu, 2013).

The literature distinguishes between two types of BM dynamics. In the first, BM dynamics (i.e., business model "evolution", "learning," "erosion" and "lifecycles") (Saebi, Lien, \& Foss, 2017) are perceived to be triggered by external factors. This type considers BM dynamics as $B M$ adaptation, that is, the process by which managers align their firms' BMs to changing business environments. The second type refers to $B M$ innovation (Casadesus-Masanell \& Zhu, 2013; Markides, 2006), which is the process through which managers actively modify their BMs, based on their internal resources, so as to achieve a competitive advantage (Saebi et al., 2017). In this article, we do not distinguish between $B M$ adaptation and innovation, but rather use the term BM modifications.

Such BM dynamics can range from incremental to radical changes (Velu, 2016). Incremental would mean minor changes to the BM components with respect to the existing $\mathrm{BM}$, whereas radical $\mathrm{BM}$ dynamics involve major changes to both BM components and the overall business logic (Daneels, 2004).

\subsubsection{Frameworks for understanding BM dynamics}

Frameworks for gaining insights into the BM dynamics of established firms such as equipment providers, typically consider BM dynamics as a way to replace an existing BM with a new one. For example, Cavalcante et al. (2011) distinguish between BM creation, extension, revision, and termination. BM creation is about getting a new BM up and running through several modifications before implementation. BM extension means adding elements to and/or expanding the value proposition, value creation, and profit equation of an existing BM. This extension is motivated by opportunities to enlarge the existing business and to exploit associated commercial opportunities. BM revision means removing and adding elements to the existing BM configuration. Such a $\mathrm{BM}$ revision implies intervening in existing processes, which in turn implies an altered business direction. Thus, BM revision is likely to involve significantly more barriers than BM extension, because it requires changes that are more fundamental. BM termination refers to abandoning an entire BM, most likely by replacing it with a new one (Cavalcante et al., 2011). Similar frameworks suggest that a new BM unfolds sequentially, which includes identifying troublesome aspects of the existing BM, revitalizing and improving its value, managing new and existing BMs simultaneously, and, finally, marginalizing BMs by reducing the reliance on old BMs (Mehrizi \& Lashkarbolouki, 2016).

Such frameworks have recently been applied in the context of digitalization. An example is the shift toward digital content in the newspaper industry. Digitalization leads to challenges in existing newspaper $\mathrm{BMs}$, rendering some traditional newspaper business components no longer viable (Pauwels \& Weiss, 2008). In the digital newspaper BM, the value proposition moves toward customized content, including news alerts and search options. As for the profit equation, online advertisements have become an important revenue stream. However, companies initially attempted to revitalize the existing model, but later had to recognize the need for a traditional BM parallel to a digital one for newspapers. Over time, the digital BM has been marginalizing the traditional BM (Pauwels \& Weiss, 2008).

\subsubsection{Obstacles limiting BM dynamics}

Three obstacles can inhibit BM dynamics. The first refers to possible conflicts between seemingly opposing old and new BMs. Such conflicts can prevent a progression of phases in the sequence of letting the new BM unfold (Doz \& Kosonen, 2010; McGrath, 2010; Teece, 2010). This obstacle occurs at the holistic level of the BM, when companies progress from an existing to a new business logic. The argument is that companies cannot run two or even more business logics in parallel. Instead, they need to specialize in one single business logic to achieve the necessary efficiency. Firms thus find themselves unable to reconfigure their assets to support the new BM, due to contradictions within the existing BM (Chesbrough, 2010).

By changing from an existing to a new BM logic, companies need to develop an approach for managing possible conflicts, e.g. opposing effects between the existing and the new BM. This requires a firm's willingness to reduce the actual or potential value of its investments in assets and organizational routines underlying the BM logic (Chandy \& Tellis, 1998). If a firm is wedded to its current resource base and is only willing to pursue new directions that conform to its existing resources - and consequently avoids initiatives that could affect them adversely - it will curtail the range of exploration of its new BM logics.

To cope with this obstacle, companies need to take advantage of "ambidexterity" within their portfolio, implying a duality of change (Doz \& Kosonen, 2010; Dunford et al., 2010; McGrath, 2010; Raisch \& Brikinshaw, 2008; Smith, Binns, \& Tushman, 2010). To pursue the exploration of new BM logics more fully, companies need to shed commitments to existing resources, even if this renders some of its past investments obsolete (Chandy, Prabhu, \& Antia, 2003; Daneels, 2004). Therefore, changing the BM logic entails phases of pursuing new opportunities by shifting the focus from exploiting current resources to exploring new ones, even if this means sacrificing current sources of profit (Levinthal \& March, 1993; March, 1991). Tronvoll, Sklyar, Sörhammar, and Kowalkowski (2020) emphasize that companies need to develop an entrepreneurial culture, focusing on novel and innovative uses of technology. Successful digital servitization requires different knowledge and competences, such as IT skills for managing and analyzing data, fostering internal collaboration and establishing external partnerships (Tronvoll et al., 2020).

The obstacle of possible conflicts between existing and new business logic is closely intertwined with the second obstacle of constraints to management cognition. Such cognitive obstacles might emerge, for example, from past successes of the existing BM. Managers may be too confident that the existing BM is still the best way forward. Managers then overlook signs of trouble, ultimately rendering the existing BM increasingly obsolete. Further cognitive constraints refer to overemphasizing mixing and/or isolating the existing and new BM, and thereby limiting the cross-fertilization between both BMs.

When companies overcome conflicts between the existing and the new business logic, as well as constraints to management cognition, they start to modify the BM components. These modifications enable companies to depart from consistent configurations of BM components (see Section 2.2.1).

Such modifications lead to the third obstacle in terms of inconsistencies in the configuration of the BM components, which need to be coupled tightly and coherently, in order to attain efficiency and to produce a good BM performance (Demil \& Lecocq, 2010). This tight coupling can create inconsistencies between BM components, when the 
modifications lead to mismatches among value proposition, value creation, and profit equation. Maintaining coherence and consistency is difficult, since interactions between components are hard to predict, and change over time (Demil \& Lecocq, 2010; Velu, 2017). This is especially true when companies modify multiple components, and ultimate outcomes depend on the interaction of all components involved (Berends et al., 2016). These inconsistencies can inhibit the BM dynamics.

\section{Research approach and empirical context}

Our empirical context is the European equipment manufacturing industry. We used a purposeful sampling process (Yin, 1994), both screening industry reports and talking to industry experts, in order to identify companies that are experienced with regard to revenue enhancement through digital offerings. We contacted 37 companies, of which 27 agreed to participate. To raise external validity, we confirmed that all participating companies represented a variety of industries, company sizes, and geographical locations. All 27 companies offer traditional products and services, and have substantial experience in providing digital offerings (see Table 2).

To systematically examine the BM dynamics for revenue enhancement through digital offerings, our research followed a sequence of iterations, switching sequentially between theoretical inputs and empirical results. The nature of the research process was therefore abductive, that is, combining deduction and induction (Dubois \& Gadde, 2002).

The description of empirical results consists of three empirical studies with three different qualitative research methods. The first study entails a series of explorative interviews, conducted with all 27 companies. These interviews were used to identify the common phases of BM dynamics. These phases describe the BM changes from a holistic business perspective. The second study, consisting of focus groups, revealed possible barriers to management cognition which would hinder progressing through the three phases. The third study consists of in-depth case studies to identify modifications to the BM components of each phase.

Since the sequence of the three qualitative studies follows a rationale in which the results of the first study informed the second one, and the results of the second informed the third, we describe the research methods together with the actual results.

\section{Study I: Identification of phases in BM dynamics}

\subsection{Explorative interviews}

We conducted interviews with a senior manager from each of the 27 companies. These managers were selected according to three criteria: the amount of time the managers had worked in the company, the managers' knowledge of $\mathrm{BM}$, and their work experience on the initiatives for converting digital offerings into revenue enhancement (Kumar, Stern, and Anderson 1993). Over a period of eight months, our research team met the managers personally and asked them about the chronology of converting digital offerings into revenue enhancements. Each interview was about one hour long, and we used questions that explore this chronology from a holistic BM perspective, recording and transcribing all interviews. The interview transcripts were organized along the chronology and distinct phases of BM dynamics. We analyzed each interview transcript individually, by jointly reviewing the descriptions in order to identify common phases (Eisenhardt \& Graebner, 2007; Gibbert, Ruigrok, \& Wicki, 2008), which we then compared by using pattern matching with the existing BM literature. This procedure enabled us to identify common phases across all 27 companies in alignment with the BM literature.
Table 2

Observed company characteristics.

\begin{tabular}{|c|c|c|c|}
\hline Company case & $\begin{array}{l}\text { Approximate } \\
\text { number of } \\
\text { employees }\end{array}$ & Headquarter & Digital offerings \\
\hline $\begin{array}{l}\text { Equipment } \\
\text { manufacturer of } \\
\text { printing presses }\end{array}$ & 12,000 & Germany & $\begin{array}{l}\text { Printing-process } \\
\text { optimization } \\
\text { remote maintenance } \\
\text { performance } \\
\text { guarantees }\end{array}$ \\
\hline $\begin{array}{l}\text { Equipment } \\
\text { manufacturer for } \\
\text { food processing }\end{array}$ & 8000 & Switzerland & $\begin{array}{l}\text { Machine } \\
\text { optimization and } \\
\text { food control } \\
\text { remote maintenance }\end{array}$ \\
\hline $\begin{array}{l}\text { Equipment } \\
\text { manufacturer for die } \\
\text { casting }\end{array}$ & 3000 & Switzerland & $\begin{array}{l}\text { Real-time } \\
\text { monitoring and } \\
\text { control } \\
\text { predictive analytics } \\
\text { automation } \\
\text { solutions for higher } \\
\text { availability and } \\
\text { faster cycle times } \\
\text { real-time } \\
\text { monitoring and } \\
\text { control }\end{array}$ \\
\hline $\begin{array}{l}\text { Equipment } \\
\text { manufacturer for } \\
\text { power transmission } \\
\text { and paper processing }\end{array}$ & 19,000 & Germany & $\begin{array}{l}\text { Applications for } \\
\text { process } \\
\text { optimization and } \\
\text { smart maintenance } \\
\text { VR training }\end{array}$ \\
\hline $\begin{array}{l}\text { Industrial service } \\
\text { provider for the oil } \\
\text { and gas industry }\end{array}$ & 43,000 & USA & $\begin{array}{l}\text { Data analytics, AI } \\
\text { solutions } \\
\text { applications for } \\
\text { planning, } \\
\text { simulation and } \\
\text { process } \\
\text { optimization } \\
\text { condition } \\
\text { monitoring } \\
\text { predictive } \\
\text { maintenance }\end{array}$ \\
\hline $\begin{array}{l}\text { Equipment } \\
\text { manufacturer of } \\
\text { aircraft engines }\end{array}$ & 48,000 & USA & $\begin{array}{l}\text { Data analytics and } \\
\text { visualization } \\
\text { performance and } \\
\text { risk management } \\
\text { prognostic health } \\
\text { management } \\
\text { operations } \\
\text { optimization }\end{array}$ \\
\hline $\begin{array}{l}\text { Manufacturer of laser } \\
\text { cutting machines }\end{array}$ & 15,000 & Germany & $\begin{array}{l}\text { Software for process } \\
\text { planning, quote } \\
\text { calculation, } \\
\text { customer order } \\
\text { management, } \\
\text { programming } \\
\text { condition } \\
\text { monitoring } \\
\text { remote control }\end{array}$ \\
\hline $\begin{array}{l}\text { Equipment } \\
\text { manufacturer of } \\
\text { cutting machine tools }\end{array}$ & 8000 & Germany & $\begin{array}{l}\text { App-based interface } \\
\text { with multi-touch } \\
\text { operation } \\
\text { software for } \\
\text { planning, } \\
\text { preparation, } \\
\text { production, } \\
\text { monitoring } \\
\text { app builder }\end{array}$ \\
\hline $\begin{array}{l}\text { Equipment } \\
\text { manufacturer of } \\
\text { injection molding } \\
\text { machines }\end{array}$ & 7000 & Austria & $\begin{array}{l}\text { Intelligent } \\
\text { monitoring } \\
\text { predictive } \\
\text { maintenance } \\
\text { remote maintenance } \\
\text { self-regulating } \\
\text { systems } \\
\text { calculation app }\end{array}$ \\
\hline $\begin{array}{l}\text { Equipment } \\
\text { manufacturer of }\end{array}$ & 3000 & Switzerland & $\begin{array}{l}\text { Mobile production } \\
\text { monitoring } \\
\text { ontinued on next page) }\end{array}$ \\
\hline
\end{tabular}


Table 2 (continued)

\begin{tabular}{|c|c|c|c|}
\hline Company case & $\begin{array}{l}\text { Approximate } \\
\text { number of } \\
\text { employees }\end{array}$ & Headquarter & Digital offerings \\
\hline precision machines & & & messenger app \\
\hline $\begin{array}{l}\text { for the mold-making } \\
\text { industry }\end{array}$ & & & $\begin{array}{l}\text { live remote } \\
\text { assistance } \\
\text { pro-active } \\
\text { maintenance }\end{array}$ \\
\hline $\begin{array}{l}\text { Equipment } \\
\text { manufacturer for } \\
\text { cranes and lifting } \\
\text { equipment }\end{array}$ & 16,000 & Finland & $\begin{array}{l}\text { Smart maintenance } \\
\text { remote monitoring } \\
\text { remote support }\end{array}$ \\
\hline $\begin{array}{l}\text { Equipment } \\
\text { manufacturer of } \\
\text { industrial cranes }\end{array}$ & 6000 & Germany & $\begin{array}{l}\text { Remote monitoring } \\
\text { service platform }\end{array}$ \\
\hline $\begin{array}{l}\text { Equipment } \\
\text { manufacturer for } \\
\text { grinding }\end{array}$ & 2000 & Switzerland & $\begin{array}{l}\text { Production } \\
\text { monitoring } \\
\text { remote services } \\
\text { service monitor }\end{array}$ \\
\hline $\begin{array}{l}\text { Equipment } \\
\text { manufacturer and } \\
\text { technology provider } \\
\text { for medical and } \\
\text { safety solutions }\end{array}$ & 14,000 & Germany & $\begin{array}{l}\text { Equipment locating } \\
\text { system } \\
\text { equipment } \\
\text { connectivity system } \\
\text { preventive } \\
\text { maintenance } \\
\text { remote measuring } \\
\text { training app } \\
\text { app for } \\
\text { measurement-data } \\
\text { management }\end{array}$ \\
\hline $\begin{array}{l}\text { Component } \\
\text { manufacturer for } \\
\text { power grids }\end{array}$ & 36,000 & Switzerland & $\begin{array}{l}\text { Condition } \\
\text { monitoring } \\
\text { preventive } \\
\text { maintenance } \\
\text { performance } \\
\text { optimization } \\
\text { cyber security } \\
\text { services }\end{array}$ \\
\hline $\begin{array}{l}\text { Supplier of industrial } \\
\text { robots and robot } \\
\text { software }\end{array}$ & 4000 & Switzerland & $\begin{array}{l}\text { Condition } \\
\text { monitoring and } \\
\text { diagnostics } \\
\text { predictive } \\
\text { maintenance } \\
\text { fleet assessment } \\
\text { asset optimization } \\
\text { remote control } \\
\text { simulation software }\end{array}$ \\
\hline $\begin{array}{l}\text { Equipment provider for } \\
\text { wind turbines }\end{array}$ & 25,000 & Denmark & $\begin{array}{l}\text { Condition } \\
\text { monitoring } \\
\text { smart maintenance } \\
\text { asset optimization } \\
\text { project planning } \\
\text { remote service }\end{array}$ \\
\hline $\begin{array}{l}\text { Manufacturer of } \\
\text { packaging and } \\
\text { bottling machines }\end{array}$ & 17,000 & Germany & $\begin{array}{l}\text { Data analytics for } \\
\text { value chain } \\
\text { optimization } \\
\text { augmented reality } \\
\text { support } \\
\text { machine } \\
\text { visualization (HMI } \\
\text { system) } \\
\text { digital training }\end{array}$ \\
\hline $\begin{array}{l}\text { Equipment } \\
\text { manufacturer for } \\
\text { food industry and } \\
\text { municipal vehicles }\end{array}$ & 13,000 & Switzerland & $\begin{array}{l}\text { Remote support } \\
\text { remote maintenance } \\
\text { application for fleet } \\
\text { management }\end{array}$ \\
\hline $\begin{array}{l}\text { Manufacturer of } \\
\text { material-handling } \\
\text { equipment }\end{array}$ & 18,000 & Germany & $\begin{array}{l}\text { Remote support } \\
\text { warehouse } \\
\text { management system } \\
\text { autonomous } \\
\text { material-handling } \\
\text { equipment } \\
\text { application for fleet } \\
\text { management } \\
\text { easy access to } \\
\text { vehicle via display } \\
\text { Connectivity unit }\end{array}$ \\
\hline
\end{tabular}

Table 2 (continued)

\begin{tabular}{|c|c|c|c|}
\hline Company case & $\begin{array}{l}\text { Approximate } \\
\text { number of } \\
\text { employees }\end{array}$ & Headquarter & Digital offerings \\
\hline $\begin{array}{l}\text { Manufacturer of } \\
\text { material-handling } \\
\text { equipment }\end{array}$ & & & $\begin{array}{l}\text { rental service } \\
\text { autonomous } \\
\text { material-handling } \\
\text { equipment } \\
\text { predicitve } \\
\text { maintenance } \\
\text { fleet management } \\
\text { access control } \\
\text { cockpit }\end{array}$ \\
\hline $\begin{array}{l}\text { Manufacturer of } \\
\text { industrial tools and } \\
\text { equipment }\end{array}$ & 34,000 & Sweden & $\begin{array}{l}\text { Software solutions } \\
\& \text { optimization } \\
\text { services } \\
\text { data-driven uptime } \\
\text { management } \\
\text { data-driven } \\
\text { maintenance } \\
\text { management } \\
\text { data-driven } \\
\text { efficiency } \\
\text { management } \\
\text { data visualization } \\
\text { remote maintenance }\end{array}$ \\
\hline $\begin{array}{l}\text { Manufacturer of air } \\
\text { compressors }\end{array}$ & 46,000 & Germany & $\begin{array}{l}\text { Remote } \\
\text { maintenance } \\
\text { application for } \\
\text { process } \\
\text { optimization and } \\
\text { efficiency } \\
\text { data visualization } \\
\text { predictive } \\
\text { maintenance }\end{array}$ \\
\hline $\begin{array}{l}\text { Manufacturer of } \\
\text { construction and } \\
\text { agriculture } \\
\text { machinery }\end{array}$ & 46,000 & Switzerland & $\begin{array}{l}\text { Positioning system } \\
\text { data reporting and } \\
\text { visualization } \\
\text { simulation software } \\
\text { for planning and } \\
\text { training } \\
\text { fleet management } \\
\text { through } \\
\text { connectivity and } \\
\text { tracking } \\
\text { smart maintenance, } \\
\text { remote support } \\
\text { smart camera } \\
\text { display controller }\end{array}$ \\
\hline $\begin{array}{l}\text { Manufacturer of plants } \\
\text { and machinery }\end{array}$ & 16,000 & Germany & $\begin{array}{l}\text { Digital marketplace } \\
\text { for customers } \\
\text { application } \\
\text { development } \\
\text { data visualization } \\
\text { data analytics }\end{array}$ \\
\hline $\begin{array}{l}\text { Transportation } \\
\text { equipment provider }\end{array}$ & 29,000 & Germany & $\begin{array}{l}\text { Condition } \\
\text { monitoring } \\
\text { data visualization } \\
\text { applications for } \\
\text { asset management } \\
\text { and process } \\
\text { optimization } \\
\text { predictive } \\
\text { maintenance } \\
\text { smart security } \\
\text { remote service }\end{array}$ \\
\hline $\begin{array}{l}\text { Manufacturer of wind } \\
\text { turbines }\end{array}$ & 8000 & Spain & $\begin{array}{l}\text { Smart-service } \\
\text { planning } \\
\text { diagnostic services } \\
\text { data analytics } \\
\text { remote monitoring } \\
\text { and maintenance }\end{array}$ \\
\hline
\end{tabular}

\subsection{Results: three phases of BM dynamics}

Our research question addressed in Study I is: What phases do companies go through on their way to achieving revenue enhancement 
through digital offerings?

As illustrated in Fig. 2, our interviews reveal that a product-oriented $\mathrm{BM}$ is the starting point for BM dynamics. The common pattern emerged subsequently that BM dynamics occur in three phases, each determined by changes in the overall business logic. Managers adapt their own templates to the core business logic. They extend their digital offerings, which in turn changes the overall BM configuration.

In the first phase, companies progressed from their product-oriented BM toward augmenting products through a "hardware-plus" logic. Companies started to provide digital offerings (e.g. software features for products, smart services) and bundled them with product offerings, in order to improve smooth and personalized customer experiences. They used these digital offerings to augment the price premium and/or to differentiate the product offering. Companies focused on this "hardware plus" as their single business logic in the first phase.

In Phase 2, companies departed from the sole "hardware-plus" business logic for creating customer value. Instead, companies established a portfolio of multiple logics, recognizing that an increasing share of customer value is determined by digital offerings such as software applications and outcome-based services. These digital offerings enabled them to solve more complex customer problems, such as improving customer process efficiency (Tuli et al., 2007). However, by keeping digital offerings integrated into the product offering, customers failed to recognize its value. Companies were creating new BMs to enable both offerings to unfold successfully, converting services into an outcome-based BM and moving toward software BMs.

In the third phase, the business logic turned toward establishing a platform logic for integrating and parallelizing these multiple logics. The ability of hardware products to exchange data through the internet drives this platform logic. Companies used digital platforms to store, analyze and combine data on the entire customer manufacturing system, in order to solve complex and strategically more important customer problems concerning entire asset systems. They created complex datadriven solutions, including software applications and services such as prescriptive maintenance and performance guarantees. Companies embraced partnerships with other companies and built business ecosystems, in order to include external capabilities, to broaden the scope of solutions and to make platforms more attractive.

Companies do not automatically progress from Phase 1 to 3, but need to overcome certain barriers, which form the main focus of Study II.

\section{Study II: identification of barriers to BM modification}

\subsection{Focus group method}

We invited participants from the interview series to attend three focus groups. In total, 25 of the 27 companies participated, meaning that each group consisted of 9 to 12 participants, representing eight or nine companies. Each group met for $6 \mathrm{~h}$.

In each focus group, we presented our three phases for identifying and discussing possible barriers to BM modification. One member of the research team moderated the focus group discussions. Given the general proficiency of the participants, we limited our involvement to summarizing discussion points on flip charts and assisting participants in describing their reasoning. Given that focus groups ensure rich data through insights obtained from expert interaction (Morgan, 1988), we shared the focus group protocols with participants and asked for feedback and comments.

During the focus groups, participants discussed the barriers in each phase. We applied content analysis (Eisenhardt \& Graebner, 2007) to aggregate the focus group discussion into the main barriers that could potentially limit progress along these phases.

\subsection{Results: identification of barriers between the three phases of BM dynamics}

Our research question addressed in Study II is: What barriers limit progress along the phases and hinder companies from advancing to the next phase of achieving revenue enhancement through digital offerings?

The content analysis revealed three main barriers. First, we observed what is best termed a confidence barrier, limiting the progression from Phase 1 to 2 . Second, we discovered a mixing barrier limiting the

A Framework for converting digital offerings into revenue enhancement

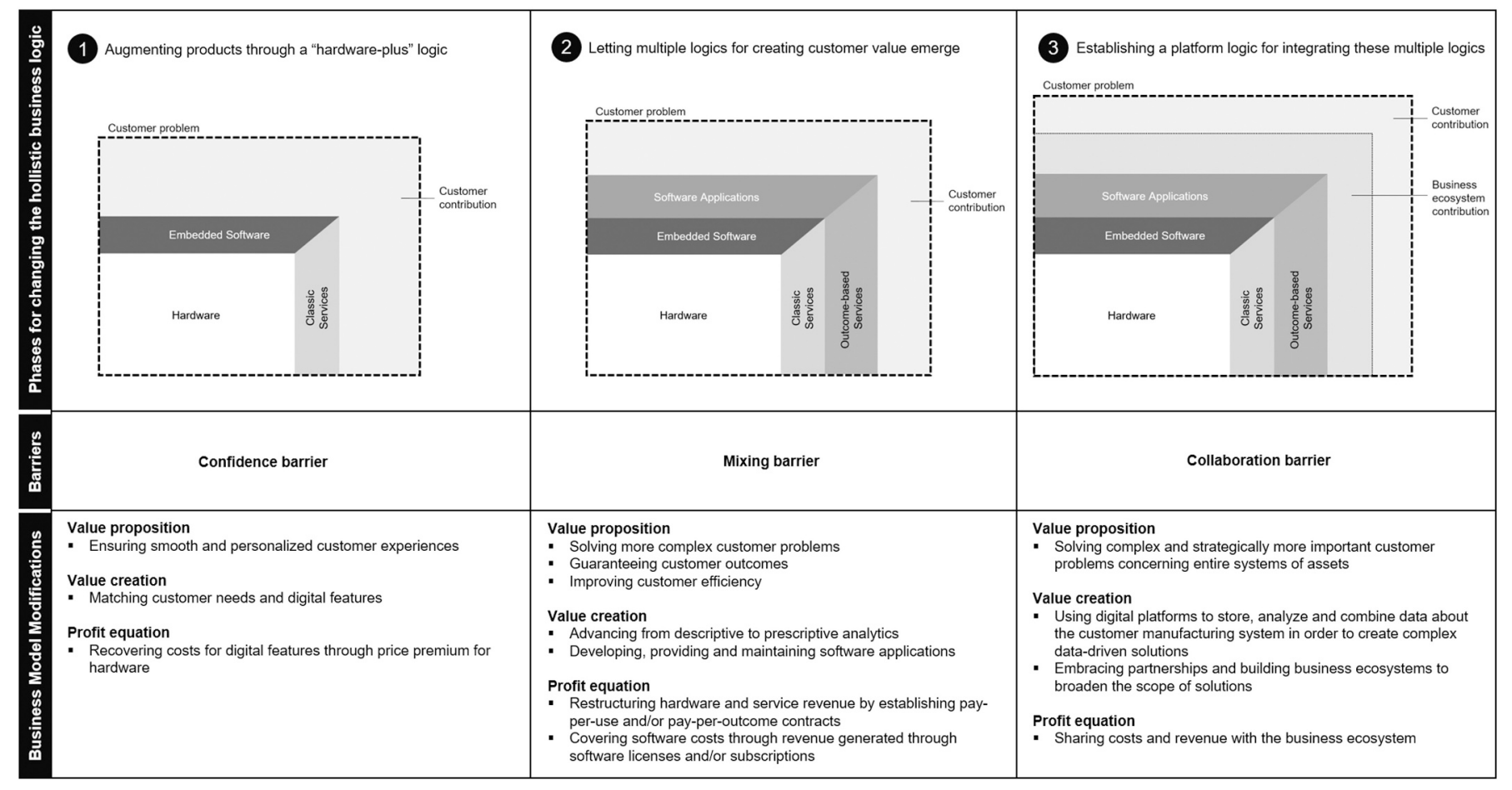

Fig. 2. A Framework for converting digital offerings into revenue enhancement. 
emergence of multiple business logics. Third, we identified a collaboration barrier constraining the integration of these three BMs into a platform BM. The next three sections discuss these barriers in more detail.

\subsubsection{Confidence barrier limiting the progress from phase 1 to phase 2}

Companies tend to continue advancing their "hardware-plus" business logic for too long, while simultaneously delaying the creation of a portfolio of multiple business logics for achieving customer value. Turning the product-oriented BM into a "hardware-plus" BM is a financially sensible approach (at least in the short-term) for dealing with the tendency towords more and more customer value being generated through service and software offerings. However, this "hardware-plus" logic is still closely related to the traditional product-oriented BM and can be considered as merely a revitalization of the old business logic. Once companies have succeeded in revitalizing their old logic through the "hardware-plus" logic, they may believe they can do so ad infinitum. For example, a CEO stated "We were initially confident that continuing the 'hardware-plus' approach could solve our problem... We kept our faith in the viability of the 'hardware-plus' logic and were sure that it would continue to ensure competitive advantages... becoming blind to the fact that our customers still see us only as a seller of hardware boxes... not recognizing the real value of all the software and services we offered together with our hardware... Customers increasingly looked for better hardware prices, putting a lot of pressure on our profitability." This statement suggests that companies should be aware of the confidence barrier, especially if short-term success in rescuing a troubled BM compromises long-term opportunities for developing new BMs.

The confidence barrier does not mean that managers are blind to the signs of trouble, for example, that customers do not recognize the value of software and services, leading to eroding margins. Rather, it is about managers placing too much faith in their ability to save the old product logic by trying to revitalize the idea of augmenting the product offering with software and services. Although companies might be able to revitalize their product logic within a short time frame, excessive reliance on this phase can obstruct new ways of creating customer value. This might lead to business failure and losing business to competitors. As the experience of the focus group participants shows, early failure in revitalizing the "hardware-plus" logic might be an advantage, provided such failures makes them reflect deeply on the overall business logic through systematic scrutiny of alternative BMs.

Overcoming the confidence barrier enables companies to progress successfully from Phase 1 to Phase 2.

\subsubsection{Mixing barrier limiting phase 2}

During the creation of multiple logics for creating customer value in Phase 2, there are complex relations between the old business logic and the newly emerging ones. They involve trade-offs between reaping the fruits of cross-fertilization and preventing the damage caused by crosspenalizing among BMs. Thus, the challenge is not to mix multiple relations between old and multiple new business logics. More specifically, firms need to exploit synergies, while also preventing destructive competition and interference between them. Our focus group participants stressed the need to rely on a separation approach. For instance, a sales officer explained that: "We kept the new outcome-based business logic in a separate sales department, ensuring that the dominant perspective of selling equipment and services did not interfere with the further development of this business model." Similarly, a vice president of the software business highlighted that: "We made our digital unit responsible for pushing the software BM ... it included a separate sales channel, ensuring that the new application sales did not interfere with our existing sales activities."

While such separation mechanisms seem rational, focus group participants reported being trapped within mixing mechanisms. They recognized a need to cross-subsidize the outcome-based and software BMs. Establishing outcome-based models takes a fair amount of time, until a sufficient amount of revenue is generated. In addition, such revenue entails higher risks if companies do not achieve the expected outcomes and/or customers use the product differently. Similarly, software BMs imply high software development costs, which need to be covered by annual software subscription revenue. Companies tend to mitigate these risks through revenue deriving from traditional hardware and service sales (Ulaga \& Reinhardt, 2011). Thus, companies address the resulting monetization gaps through the integration of financial mechanisms. This makes it difficult to strike a balance between separation and mixing practices, which should be applied carefully to different aspects of the three BMs. Companies can only nurture their two new BMs for creating customer value, if they keep them partially separated, while benefiting from their past investments in the old BM.

Companies can overcome the mixing barrier if they are able to carefully and constantly examine the relationship between the multiple business logics. They need to pay attention to potential interfering, competitive, and synergic relations.

\subsubsection{Collaboration barrier limiting phase 3}

A collaboration barrier limits the platform business logic in Phase 3. Our focus group discussions revealed both internal and external collaboration barriers. The internal barrier is the result of emphasizing separation mechanisms, so as to enable outcome and software BMs to gain sufficient momentum for the unfolding process. However, these separation mechanisms can weaken internal collaboration. Nevertheless, such collaboration is necessary to avoid the long-term tendency for the three BMs to be treated in too isolated a manner, thus preventing sufficient cross-fertilization.

The external collaboration barrier relates to the specific characteristics of platform markets. Managing the BM dynamics in the context of platforms is a complex task, since many different companies need to contribute in order to make a platform logic successful. However, experience with platforms (e.g. search engines, online marketplaces, maps, music services, etc.) reveals a tendency for only a few companies to dominate the ecosystem, thereby capturing a disproportionate share of the economic value. Platforms seem to lead to a "winner takes it all" and quasi-monopoly situation (Parker \& Van Alstyne, 2011). Thus, Phase 3 can only unfold if there is sufficient trust among collaboration partners and if each partner gains a fair share of the economic value. A senior marketing executive from a jet engine manufacturer explained this collaboration barrier as follows: "Our customers were complaining, because the piece of metal surrounding the engine was burning out too quickly ...decreasing...fuel efficiency... We wanted one of our platform partners to look at the engine data to identify possible reasons for the intensive burning... The partner invested a lot of money to identify that dust and pollution in certain flight patterns were causing the problem... Thus, it was important that the partner trusted us to commercialize the data analytics together and ... that the partner would benefit sufficiently from revenue sharing...".

The collaboration barrier can inhibit establishing a platform business logic in Phase 3. Companies can overcome this barrier if they find suitable mechanisms for value co-creation, revenue sharing and trust among partners.

If companies can overcome these three barriers, they can advance along the three phases, through modifying BM components (value proposition, value creation, and profit equation). These BM modifications were investigated in Study III.

\section{Study III: in-depth case studies on BM modifications}

\subsection{In-depth case study method}

Our research question addressed in Study III is: How do companies modify BM components in each phase in order to achieve revenue enhancement through digital offerings?

To study BM component modifications in each phase, we applied an explorative in-depth case study method. Among the 27 companies, we selected one company for each modification, based on their suitability for BM component modification and their willingness to participate in 
data collection for case studies. Through these case studies, we identified key modifications in the BM components, thus revealing revenue enhancement (Eisenhardt \& Graebner, 2007; Gibbert et al., 2008).

In each case study, we interviewed 5 to 6 executives about key modifications in the BM components. We phrased questions in an unobtrusive and non-directive manner, to avoid the pitfalls of excessively active listening (McCracken, 1988). We supplemented interview data with secondary data (e.g. company literature, internal documents). These data were used to develop case reports about BM modifications. To ensure internal validity and reliability, we asked participants to review the reports themselves.

We began our data analysis by undertaking open coding, paragraph by paragraph, to identify critical modifications in value proposition, value creation, and profit equation in the case reports. These modifications were converted into descriptive codes (Strauss \& Corbin, 1990). Our decision to include the BM modifications relied on the following criteria: (1) that multiple interviewees within a single company mentioned the modification; and (2) that the modification extended beyond the obvious to provide meaningful and genuinely useful conclusions (Tuli et al., 2007; Ulaga \& Reinartz, 2011).

As a check on the reliability of our findings, we assessed the interjudge reliability of our coding (Perreault \& Leigh, 1989). We asked two independent judges to review the coding plan and instructions, as well as the verbatim transcript, so as to verify the accuracy of the business model modifications that we identified. The index of reliability reached 0.83 , above the 0.7 threshold recommended for qualitative research (Rust \& Cooil, 1994).

\subsection{BM modifications}

In order to enhance revenue, firms follow various iterations of BM modifications, encompassing the adjustment of value proposition, value creation, and profit equation. As illustrated in Fig. II, our identified logic of BM dynamics to achieve revenue enhancement incorporates three distinct phases. Phase 1 is called "Augmenting products through a "hardware-plus' logic" and was explored in Case A. Phase 2 is called "Letting multiple logics for creating customer value emerge" and includes both "converting services into an outcome-based BM", studied in Case B, and "exploring a software BM", examined in Case C. Phase 3 is called "Establishing a platform logic for integrating the multiple logics" and was investigated in Case D. With each phase advancement, firms are able to address a more complex customer problem. They thereby improve their value proposition and reduce the necessary customer contribution by adding digital product and service layers, such as software offerings, outcome-based services, and integration of the business ecosystem into value creation activities. Below, we describe the BM modifications identified in the case studies.

\subsubsection{Case A: augmenting products through a "hardware-plus" logic (phase 1)}

Case Company A, a manufacturer of laser cutting machines, illustrates the BM modifications for augmenting products through a "hardware-plus" logic. This company initially relied on a product-oriented $\mathrm{BM}$. The company recognized that digital offerings, such as duplicating the user interface of the laser cutting machine on a portable tablet pc, or equipping customers with smart glasses to assist them during equipment maintenance, are interesting ways to create new customer experiences. These experiences depend on the specific equipment, and were therefore promoted together with it. Digital offerings helped to augment the existing equipment and service offerings, and to justify the price premium.

However, customers could potentially reject such digital offerings, if they are not aligned with customer expectations about digital, smooth, and personalized customer experiences (Nylén \& Holmström, 2015). Thus, a structured and iterative innovation process for merging customer expectations with the benefits offered by digital offerings and technologies was introduced into the value-creation activities. This modification prevented the company from overemphasizing the technical possibilities of their digital offerings, rather than gaining a deep understanding of customer needs. For the abovementioned portable tablet computer, a senior service manager explained that: “.... During our innovation process, we recognized that customers' machine operators are responsible for multiple machines, and therefore keen to move around on the shop floor. But of course, they cannot carry multiple computers. Thus, only a portable computer allowing multiple user interfaces generated sufficient customer value... It was important for us to gain deeper insights into customer needs and digital features...".

As for the profit equation, such digital offerings increase customer value and help to differentiate the equipment and service offerings. Revenue enhancements occur only indirectly, increasing the revenue generated by more equipment and service sales.

6.2.2. Case B on converting services into an outcome-based BM (phase 2)

Case Company $\mathrm{B}$, a transportation equipment provider, illustrates $\mathrm{BM}$ modifications enabling the emergence of multiple logics for creating customer value. Company B demonstrates the conversion of services into an outcome-based BM, and had already proceeded toward a "hardwareplus" business logic. However, Company B recognized that the differentiation advantages of augmenting the transportation equipment with digital offerings were becoming progressively more mature. New differentiation advantages are triggered by customers demanding outcomes rather than equipment together with services. They demand improvements and guarantees on equipment availability, uptime, usage, and performance (Ulaga \& Reinartz, 2011). Accordingly, Company B shifted its value propositions toward guaranteeing equipment usage and levels of performance (e.g. 98\% train availability).

A senior manager explained that “... one of our customers demanded an increase in the number of trains running per hour on a selected train track from 24 to 27. But to achieve this increased performance, this customer was not willing to increase the total number of trains. Instead, the customer's purchase department asked us for a better utilization of the train capacity..." Thus, Company B responded to such a customer demand by developing digital services utilizing train data to minimize breakdowns and maximize availability.

These digital offerings are embedded in classic services, turning, for example, maintenance into prescriptive maintenance services. Company $\mathrm{B}$ modified its value-creation activities from descriptive (identifying train failure) to diagnostic (explaining train failure), predictive (forecasting train failure), and prescriptive (recommending actions to avoid train failure).

To achieve such changes in the value-creation activities, the profit equation needs to take into consideration Company B's investments in train connectivity and data analytics, and the costs of accessing, monitoring, and analyzing train usage and performance data. These costs pay off by reducing service costs. Company B reported that it can now more accurately schedule necessary service activities (inspections, repair, and/or maintenance) before they actually occur. This improves the capacity utilization in Company B's service organization and decreases the service costs.

In addition, these digital offerings facilitated the value proposition of having customers pay for usage and/or performance (i.e. pay-per-use, payment schemes according to availability levels, penalties for not achieving performance levels) and aligning costs with a customer's level of product usage. For Company B, the profit equation included various payment options (e.g. train availability of $90 \%, 95 \%$, or $98 \%$, or paying per train kilometer, bonus and/or penalties for (not) achieving availability or punctuality goals, etc.).

As a result, this outcome-based payment scheme did not enhance revenue directly. Company B substituted product and service revenue with recurring revenue generated through pay-per-use and/or pay-forperformance payment schemes. Since these schemes extend over a longer period and do not generate revenue immediately, there could be a 
certain temporary reduction. Company B did not report such a reduction, and instead, the outcome-based BM enhanced revenue by attracting additional customer segments. These segments were sensitive to equipment prices, or lacked sufficient expertise for train operations. Thus, they fostered the idea of paying only when the train is available or for the kilometers the train is actually running.

\subsubsection{Case $C$ on exploring a software BM (phase 2)}

Case Company $\mathrm{C}$, an equipment manufacturer specializing in the food processing industry, demonstrates the software BM. Case Company $\mathrm{C}$ extended its digital offerings through a software application stack, in addition to its equipment and classic services. Three typical examples include software applications for scanning food agency sites, news and social media to identify food safety alerts in real time; software applications for silo bin monitoring to control food storage conditions at any time; and software applications for dosing, mixing, refining and conching in chocolate production.

Company C modified its BM components in the following way. The value proposition departed from a hardware and classic service focus and concentrated on data about equipment condition and usage. A senior manager explained that "...customers benefit from the application for chocolate production through more efficient processes and increased line efficiency, and consistantly high overall equipment efficiency (OEE)... but we went as far as guaranteeing a certain OEE level..." This means that, compared to outcome-based BM, customer value was not proposed in terms of guaranteeing certain customer outcomes. Instead, Company C proposed value by obtaining and analyzing data about customer processes. This, of course, required new value-creation activities to enhance software development, as well as activities for developing complex data models to link input data on equipment parameters to improvements in the customer process.

The profit equation was modified in order to sell software applications as annual subscription fees. The costs of developing the software applications were covered by annually recurring software revenue. Revenue was generated by offering customers a trial version of their applications in order to convince them of the application benefits. After the trial period, Company $\mathrm{C}$ offered customers a subscription to the software application for an annual subscription fee. In Company C, such subscription fees for software applications on thermal processing expertise reached about 75,000 Euros to 100,000 Euros. Accordingly, this software $\mathrm{BM}$ led to a software application stack in the form of additional digital offerings, thus directly enhancing revenue.

\subsubsection{Case D on exploring platform BMs (phase 3)}

Case Company $\mathrm{D}$, an equipment provider for wind turbines, is a good example of BM modifications when establishing a platform logic for integrating these multiple logics. This equipment provider succeeded with a business logic for which customer value is created by a mix of "hardware-plus" offerings, guaranteeing outcomes and providing software applications. Company D had been operating multiple BMs ("hardware-plus" BM, outcome-based BM, and software-subscription $\mathrm{BM})$, but there was an increasing need to integrate these BMs through introducing a platform logic.

Company D recognized that establishing such a platform business logic requires a value proposition extending beyond their own equipment and services for wind energy generation. As a General Manager stated: “...we now continuously monitor 16,000 turbines and provide... services for... guaranteeing turbine availability and productivity... but in the future we have to go beyond wind turbines ... and focus on the entire range of wind power generation assets."

Instead, the platform business logic enabled Company D to address more complex needs regarding the entire electricity generation process through wind power (Hagiu \& Wright, 2015). Company D went beyond guaranteeing outcomes such as uptime and the availability of wind turbines, and selling software applications. Rather, the introduction of the platform BM aimed at raising the efficiency of all the wind power generation assets.

Such a value proposition required value creation activities beyond the bounds of Company D. The company established the building blocks for the platform (e.g. digital twins for wind park assets, data analytics on wind park operation, customer outcomes on predicting and optimizing the performance of wind power assets). In addition, Company D started to embrace a business ecosystem and has developed a partner program for providing a comprehensive set of benefits (e.g. co-investments and revenue-sharing models) to help partners accelerate their own valuecreation activities on the platform. It encouraged its partners to define specific roles for contributing to these building blocks in the valuecreation activities (e.g. consulting partners, application developers, system integrators, technology partners, or connectivity partners). Company D assisted partners in this specialization through offering certain tools and training (e.g. sales and technical training, application developer tools, technical support, marketing resources, legal support, business development funds, etc.). The clarification of their valuecreation roles increased the attractiveness of Company D's platform, thus motivating partners and customers to utilize it.

Company D modified its profit equation by sharing the necessary investments, implementation costs, and revenue with the collaboration partners, creating fair economic value for each partner. Accordingly, digital offerings associated with the platform enhanced revenue through revenue sharing.

\section{Discussion}

\subsection{A framework for BM dynamics when converting digital offerings into revenue enhancement}

While technologies (e.g. IoT, big data, and AI) for enabling digital offerings and BMs have been emerging research topics for some years now, little systematic research has examined the BM dynamics for converting digital offerings into revenue enhancement. Our starting point was the observation that equipment manufacturers invest in new digital offerings. However, instead of digital offerings leading to revenue enhancement, companies often face the digital paradox, that despite these investments, companies do not earn the expected return.

Our framework suggests that BM dynamics can lead to the digital paradox which limits revenue enhancement. For example, we show that "hardware-plus" business logic in Phase 1 and outcome-based BM in Phase 2 do not directly enhance revenue. Only software in Phase 2 and platform business logic in Phase 3 lead to direct revenue enhancement. In addition, barriers to management cognition, as well as temporal inconsistencies in the modification of BM components, might limit revenue enhancement.

Our research findings provide stimulating new insights for both academics and practitioners with regard to the themes of digital offerings and BM dynamics. Of course, these findings are limited in their application, because we chose 27 companies according to their degree of appropriateness, rather than their representativeness of European equipment manufacturing industries (Yin, 1994). Moreover, our results are qualitative, highly aggregated and somewhat anecdotal in nature due to the holistic approach and the corresponding methodology of our studies. Therefore, the extent to which our findings are generalizable and applicable to other industries and other geographical areas remains unclear. Moreover, we focused on three BM key components: value proposition, value creation (delivery), and profit equation (Ghezzi et al., 2015; Teece, 2010). There are, of course, other possible conceptualizations of BM components (Osterwalder \& Pigneur, 2010; Wirtz et al., 2016). Focusing on a different BM concept might lead to different results. Accordingly, these limitations must be kept in mind when considering our theoretical and managerial implications. 


\subsection{Theoretical implications}

Our findings enhance the multifaceted nature of BM dynamics and the interplay between holistic business logic, management cognition and BM components. One of the distinguishing characteristics of the BM dynamic, compared to digital innovations, stems from the fact that it straddles both component and holistic aspects (Teece, 2010; Zott, Amit, \& Massa, 2011). This implies that BM dynamics triggered by digital offerings need to take place at the overall business-logic level, as well as that of its BM components. Constraints to management cognition play a vital role in the interplay between these levels. As a result, our framework model reveals a complex BM dynamic through which digital offerings can lead to revenue enhancement.

The findings also add the following important aspects to the obstacles limiting BM dynamics: a sequence of distinct phases in the BM dynamics, constraints to management cognition, and the configuration of BM components.

\subsubsection{Sequence of distinct phases in BM dynamics}

Altogether, this sequence of phases substantiates the notion of continuous change in BMs, suggesting that business models are frequently in states of disequilibrium (Demil \& Lecocq, 2010).

Our sequence of phases (Phase 1: augmenting products through a "hardware-plus" logic, Phase 2: enabling multiple logics for creating customer value to emerge, Phase 3: establishing a platform logic for integrating these multiple logics) suggests that digital offerings do not simply shift from an old business logic to a new one. Digital offerings do not automatically trigger a change from the existing (product-oriented) $\mathrm{BM}$ to a new (digital) one. BM dynamics are much more complex.

Multiple new business logics emerge along these phases, which progressively marginalize the old, product-oriented business logic. But even in Phase 3, "hardware-plus" logic remains an important element. Phase 1 on augmenting products through a "hardware-plus" logic, combines the idea of realizing that the old business logic is becoming more troublesome, with that of revitalizing the old business logic. Phase 1 is close to the idea of $\mathrm{BM}$ revision, whereas Phase 2 is related more to BM extension (Calvacante et al., 2011). Phase 2 extends the idea of parallelizing the old and new business logics, being about letting multiple logics emerge and keeping them parallel to the "hardware-plus" logic. Phase 3 implies not simply marginalizing the old business logic, but rather integrating these multiple business logics through a platform business logic. This logic resonates with the discussion on codevelopment partnerships in open business models. Costs and revenue-sharing models shape the business ecosystem surrounding the platform, when it comes to the development of new digital services and software applications (Chesbrough \& Schwartz, 2007).

While Phase 1 entails relative incremental changes in both the business logic as well as the BM components, Phase 2 represents a more radical shift in the business logic and BM components. Interestingly, this shift is not about replacing the "hardware-plus" BM, but rather about managing multiple business logics simultaneously. In Phase 2, companies keep three BMs parallel, suggesting that they manage a portfolio of three business logics and/or BMs ("hardware plus", outcome-based services, and software subscriptions), rather than converging these three BMs again into a single one. This portfolio (Benson-Rea, Brodie, \& Sima, 2013; Sabatier, Mangematin, \& Rousselle, 2010) consists of different ways in which equipment providers embrace value propositions, value creation, and the profit equation. In Phase 3, companies seem to focus on cross-fertilization of these three BMs through embracing a platform BM (Zhu \& Iansiti, 2012). This cross-fertilization is an important internal collaboration factor, whereas embracing a business ecosystem requires more external collaboration. Phase 3 is similar to the idea of opening up BMs through establishing a codeveloping mechanism (Chesbrough \& Schwartz, 2007). Similar to Phase 2, Phase 3 represents a more radical shift when embracing a business ecosystem.
Over time, such BM portfolios managed through a platform logic marginalize analog business logic and cultivate a digital logic. Our findings strengthen the idea that digitalization allows portfolios of BMs to flourish. To substantiate whether digital offerings trigger a shift toward BM portfolios, future researchers could deepen the notion of multiple digital BMs that companies follow, instead of specializing in a single digital BM. They could investigate how companies govern BM portfolios by mitigating cannibalization and creating synergies between various models (Benson-Rea et al., 2013).

\subsubsection{Constraints in the management cognition}

Our confidence, mixing, and collaboration barriers support and supplement the existing literature on constraints to management cognition. The confidence barrier has been mentioned in previous studies. The mixing barrier has also been highlighted in the existing literature, interpreting it as a limitation when moving from an existing to a new BM. Our findings suggest that mixing barriers can also occur when multiple BMs emerge within a company. Our collaboration barrier reflects the recent discussion on open BMs, as companies start to move from a BM in a single company, to BMs in an entire business ecosystem (Chesbrough, 2010). In addition to collaboration barriers among business partners within a business ecosystem, our findings indicate a need to collaborate smoothly across multiple business logics and BMs within a single company. In such business ecosystems, trust in the mutual benefits when sharing costs and revenues becomes a key issue (e.g. Leminen, Westerlund, Rajahonka, \& Siuruainen, 2012).

\subsubsection{Configuration in the BM components}

The modifications that we outline offer a more refined view of BM configurations. The described BM modifications for "hardware-plus", outcome-based, software, and platform BMs represent a consistent configuration of value proposition, value creation, and profit equation, in order to ensure competitive advantage. However, companies should be aware that these modifications might entail deviations from consistent configurations and cause temporary inconsistencies (Bohnsack, Pinkse, \& Kolk, 2014; Fjeldstad \& Snow, 2018). BM modifications are likely to fail if companies are not able to cope with such inconsistencies (Smith et al., 2010; Velu, 2017).

The described configuration of BM components for implementing the "hardware-plus", outcome-based, software BMs, platform logic substantiates the existing literature on product, service, software, and platform BMs. The latter offers a particularly interesting future research direction. While the platform literature has largely focused on transaction platforms and on platforms as multi-sided markets in the consumer context, our findings suggest that platforms also play a vital role in the business-to-business context.

Our findings advance knowledge on BM dynamics when turning digital offerings into revenue enhancement, and provide useful directions for further research. Of course, our three phases, barriers and modifications in the BM components are not exhaustive; there may be even more. Our findings should stimulate further research on testing and extending our framework through more fine-grained and additional phases, barriers, and modifications. In that context, a quantitative research approach might facilitate useful, measurable insights into the impact of digital offerings and corresponding $\mathrm{BM}$ modifications regarding revenue.

\subsection{Managerial implications}

In order to turn digital offerings into revenue enhancement, our framework can guide managers in coping with BM dynamics (see Fig. 2). Managers should not adopt the merely dual perspective of changing from analog to digital BMs. Instead, they can assess relevant strengths and weaknesses according to our full framework on BM dynamics; they can closely examine weaknesses, so as to make the right decisions about managing BM modifications. Managers should be aware of the three 
phases and address the possible barriers. Phase 2 seems critical, since companies should try to create multiple business logics and manage these BMs as a parallel BM portfolio. Being aware of BM successes in the past, managers should continuously modify BM components and ensure consistencies in their configurations. They should recognize that the established BM portfolio can only be sustained if managers succeed in mitigating cannibalization among the BMs, in ensuring synergies, strengthening cross-fertilization, and avoiding cross-penalization. In addition, this BM portfolio should transcend company barriers and adopt a business ecosystem perspective.

\section{References}

Amit, R., \& Zott, C. (2001). Value creation in e-business. Strategic Management Journal, 22 (6-7), 493-520.

Baden-Fuller, C., \& Mangematin, V. (2013). Business models: A challenging agenda. Strategic Organization, 11(4), 418-427.

Baden-Fuller, C., \& Morgan, M. S. (2010). Business models as models. Long Range Planning, 43(2-3), 156-171.

Baines, T., Bigdeli, A. Z., Bustinza, O. F., Shi, V. G., Baldwin, J. S., \& Ridgway, K. (2017). Servitization: Revisiting the state-of-the-art and research priorities. International Journal of Operations \& Production Management, 37(2), 256-278.

BCG. (2016). Changing the game in industrial goods through digital services. Boston Consulting Group.

Benson, M. (2015). Monetization strategies for connected products. White Paper. Exosite.

Benson-Rea, M., Brodie, R. J., \& Sima, H. (2013). The plurality of co-existing business models: Investigating the complexity of value drivers. Industrial Marketing Management, 42(5), 717-729.

Berends, H., Smits, A., Reymen, I., \& Podoynitsyna, K. (2016). Learning while (re) configuring: Business model innovation processes in established firms. Strategic Organization, 14(3), 181-219.

Bilgeri, D., Brandt, V., Lang, B., Tesch, J., \& Weinberger, M. (2015). The IoT business model builder. White Paper. Bosch IoT Lab.

Bohnsack, R., Pinkse, J., \& Kolk, A. (2014). Business models for sustainable technologies: Exploring business model evolution in the case of electric vehicles. Research Policy, 43(2), 284-300.

Bonnet, D., Buvat, J., \& Subrahmanyam, K. V. J. (2014). Monetizing the internet of things: Extracting value from the connectivity opportunity. Capgemini Consulting.

Bowman, C., \& Ambrosini, V. (2000). Value creation versus value capture: Towards a coherent definition of value in strategy. British Journal of Management, 11(1), 1-15.

Casadesus-Masanell, R., \& Zhu, F. (2013). Business model innovation and competitive imitation: The case of sponsor-based business models. Strategic Management Journal, 34(4), 464-482.

Cavalcante, S., Kesting, P., \& Ulhøi, J. (2011). Business model dynamics and innovation: (re)establishing the missing linkages. Management Decision, 49(8), 1327-1342.

Chandy, R. K., Prabhu, J. C., \& Antia, K. D. (2003). What will the future bring? Dominance, technology expectations, and radical innovation. Journal of Marketing, 67(3), 1-18.

Chandy, R. K., \& Tellis, G. J. (1998). Organizing for radical product innovation: The overlooked role of willingness to cannibalize. Marketing Research, 35(4), 474-487.

Chesbrough, H. (2010). Business model innovation: Opportunities and barriers. Long Range Planning, 43(2-3), 354-363.

Chesbrough, H., \& Rosenbloom, R. S. (2002). The role of the business model in capturing value from innovation: Evidence from Xerox Corporation's technology spin-off companies. Industrial and Corporate Change, 11(3), 529-555.

Chesbrough, H., \& Schwartz, K. (2007). Innovating business models with co-development partnerships. Research-Technology Management, 50(1), 55-59.

Cusumano, M. A., Kahl, S. J., \& Suarez, F. F. (2015). Services, industry evolution, and the competitive strategies of product firms. Strategic Management Journal, 36(4), 559-575.

Daneels, E. (2004). Disruptive technology reconsidered: A critique and research agenda. Product Innovation Management, 21(4), 246-258.

DaSilva, C. M., \& Trkman, P. (2014). Business model: What it is and what it is not. Long Range Planning, 47(6), 379-389.

Demil, B., \& Lecocq, X. (2010). Business model evolution: In search of dynamic consistency. Long Range Planning, 43(2-3), 227-246.

Downes, L., \& Nunes, P. (2013). Big bang disruption. Harvard Business Review, 91(3), $44-56$.

Doz, Y. L., \& Kosonen, M. (2010). Embedding strategic agility: A leadership agenda for accelerating business model renewal. Long Range Planning, 43(2-3), 370-382.

Dubois, A., \& Gadde, L. E. (2002). Systematic combining: An abductive approach to case research. Journal of Business Research, 55(7), 553-560.

Dunford, R., Palmer, I., \& Benveniste, J. (2010). Business model replication for early and rapid internationalisation: The ING direct experience. Long Range Planning, 43(5-6), 655-674.

Eisenhardt, K. M., \& Graebner, M. E. (2007). Theory building from cases: Opportunities and challenges. Academy of Management Journal, 50(1), 25-32.

Fischer, T., Gebauer, H., \& Fleisch, E. (2012). Service business development: Strategies for value creation in manufacturing firms. Cambridge: Cambridge University Press.

Fjeldstad, Ø. D., \& Snow, C. C. (2018). Business models and organization design. Long Range Planning, 51(1), 32-39.
Fleisch, E., Weinberger, M., \& Wortmann, F. (2014). Geschäftsmodelle im Internet der Dinge. HMD Praxis der Wirtschaftsinformatik, 51, 812-826.

Fleisch, E., Weinberger, M., \& Wortmann, F. (2015). Geschäftsmodelle im Internet der Dinge. Schmalenbachs Zeitschrift für betriebswirtschaftliche Forschung, 67(4), 444-465.

GE. (2018). Annual report (p. 2018).

Gebauer, H., Fleisch, E., Lamprecht, C., \& Wortmann, F. (2020). Growth paths for overcoming the digitalization paradox. Business Horizons, 63(3), 313-323.

Ghezzi, A., Cortimiglia, M. N., \& Frank, A. G. (2015). Strategy and business model design in dynamic telecommunications industries: A study on Italian mobile network operators. Technological Forecasting and Social Change, 90, 346-354.

Gibbert, M., Ruigrok, W., \& Wicki, B. (2008). What passes as a rigorous case study? Strategic Management Journal, 29(13), 1465-1474.

Hagiu, A., \& Wright, J. (2015). Marketplace or reseller? Management Science, 61(1), 184-203.

Hecker, D., Döbel, I., Rüping, S., \& Schmitz, V. (2017). Künstliche Intelligenz und die Potenziale des maschinellen Lernens für die Industrie. Wirtschaftsinformatik \& Management, 9, 26-35.

Iansiti, M., \& Lakhani, K. R. (2014). Digital ubiquity. How connections, sensors, and data are revolutionizing business. Harvard Business Review, 92(11), 90-99.

Johnson, M. W., Christensen, C. M., \& Kagermann, H. (2008). Reinventing your business model. Harvard Business Review, 86(12), 57-68.

Kohtamäki, M., Parida, V., Patel, P. C., \& Gebauer, H. (2020). The relationship between digitalization and servitization: The role of servitization in capturing the financial potential of digitalization. Technological Forecasting and Social Change, 151.

Kumar, N., Stern, L. W., \& Anderson, J. C. (1993). Conducting interorganizational research using key informants. Academy of Management Journal, 36(6), 1633-1651.

Lee, I. (2017). Big data: Dimensions, evolution, impacts, and challenges. Business Horizons, 60(3), 293-303.

Leminen, S., Westerlund, M., Rajahonka, M., \& Siuruainen, R. (2012). Towards IOT ecosystems and business models. In Internet of things, smart spaces, and next generation networking (pp. 15-26). Springer: Berlin, Heidelberg.

Levinthal, D. A., \& March, J. G. (1993). The myopia of learning. Strategic Management, 14 (S2), 95-112.

Liozu, S., \& Ulaga, W. (2018). Monetizing data: A practical roadmap for framing, pricing and selling your B2B offers. Value Innoruption Advisors Publishing.

March, J. G. (1991). Exploration and exploitation in organizational learning. Organization Science, 2(1), 1-147.

Markides, C. (2006). Disruptive innovation: In need of better theory. Product Innovation Management, 23(1), 19-25.

McCracken, G. (1988). The long interview. Newbury Park, CA: Sage Publications.

McGrath, R. G. (2010). Business models: A discovery driven approach. Long Range Planning, 43(2-3), 247-261.

McKendrick, D. G., \& Carroll, G. R. (2001). On the genesis of organizational forms: Evidence from the market for disk arrays. Organization Science, 12(6), 661-682.

Mehrizi, M. H. R., \& Lashkarbolouki, M. (2016). Unlearning troubled business models: From realization to marginalization. Long Range Planning, 49(3), 298-323.

Morgan, D. L. (1988). Focus groups as qualitative research. Newbury Park: Sage.

Morris, M., Schindehutte, M., \& Allen, J. (2005). The entrepreneur's business model: Toward a unified perspective. Journal of Business Research, 58(6), 726-735.

Ng, I. C., \& Wakenshaw, S. Y. (2017). The internet-of-things: Review and research directions. International Journal of Research in Marketing, 34(1), 3-21.

Nylén, D., \& Holmström, J. (2015). Digital innovation strategy: A framework for diagnosing and improving digital product and service innovation. Business Horizons, 58(1), 57-67.

Opresnik, D., \& Taisch, M. (2015). The value of big data in servitization. International Journal of Production Economics, 165, 174-184.

Osterwalder, A., \& Pigneur, Y. (2010). Business model generation: A handbook for visionaries, game changers, and challengers. John Wiley \& Sons.

Paschou, T., Rapaccini, M., Adrodegari, F., \& Saccani, N. (2020). Digital servitization in manufacturing: A systematic literature review and research agenda. Industrial Marketing Management, 89(8), 278-292.

Pauwels, K., \& Weiss, A. (2008). Moving from free to fee: How online firms market to change their business model successfully. Journal of Marketing, 72(3), 14-31.

Perreault, W., \& Leigh, L. (1989). Reliability of nominal data based on qualitative judgements. Journal of Marketing Research, 26(2), 135-148.

Raisch, S., \& Brikinshaw, J. (2008). Organizational ambidexterity: Antecedents, outcomes, and moderators. Journal of Management, 34(3), 375-409.

Rust, R. T., \& Cooil, B. (1994). Reliability measures for qualitative data: Theory and implications. Journal of Marketing Research, 31(1), 1-14.

Sabatier, V., Mangematin, V., \& Rousselle, T. (2010). From recipe to dinner: Business model portfolios in the European biopharmaceutical industry. Long Range Planning, 43(2-3), 431-447.

Saebi, T., Lien, L., \& Foss, N. J. (2017). What drives business model adaptation? The impact of opportunities, threats and strategic orientation. Long Range Planning, 50 (5), 567-581.

Seelos, C., \& Mair, J. (2007). Profitable business models and market creation in the context of deep poverty: A strategic view. Academy of Management Perspectives, 21 (4), 49-63.

Smith, W. K., Binns, A., \& Tushman, M. L. (2010). Complex business models: Managing strategic paradoxes simultaneously. Long Range Planning, 43(2-3), 448-461.

Strauss, A., \& Corbin, J. M. (1990). Basics of qualitative research: Grounded theory procedures and techniques. Inc: Sage Publications.

Teece, D. J. (2010). Business models, business strategy and innovation. Long Range Planning, 43(2-3), 172-194.

Tronvoll, B., Sklyar, A., Sörhammar, D., \& Kowalkowski, C. (2020). Transformational shifts through digital servitization. Industrial Marketing Management, 89(8), 293-305. 
Tuli, K. R., Kohli, A. K., \& Bharadwaj, S. G. (2007). Rethinking customer solutions: From product bundles to relational processes. Journal of Marketing, 71(3), 1-17.

Ulaga, W., \& Reinartz, W. J. (2011). Hybrid offerings: How manufacturing firms combine goods and services successfully. Journal of Marketing, 75(6), 5-23.

Velu, C. (2016). Evolutionary or revolutionary business model innovation through coopetition? The role of dominance in network markets. Industrial Marketing Management, 53, 124-135.

Velu, C. (2017). A systems perspective on business model evolution: The case of an agricultural information service provider in India. Long Range Planning, 50(5), 603-620.

Weinberger, M., Bilgeri, D., \& Fleisch, E. (2016). IoT business models in an industrial context. AT - Automation Technology, 64(9), 699-706.
Wirtz, B. W., Pistoia, A., Ullrich, S., \& Göttel, V. (2016). Business models: Origin, development and future research perspectives. Long Range Planning, 49(1), 36-54. Wortmann, F., Bilgeri, D., Gebauer, H., Lamprecht, C., \& Fleisch, E. (2019). Geld verdienen im IoT - aber wie? HMD Praxis der Wirtschaftsinformatik, 56, 1094-1112.

Yin, R. (1994). Case study research. Thousand Oaks: Sage Publications.

Yoo, Y., Boland, R. J., Jr., Lyytinen, K., \& Majchrzak, A. (2012). Organizing for innovation in the digitized world. Organization Science, 23(5), 1398-1408.

Zhu, F., \& Iansiti, M. (2012). Entry into platform-based markets. Strategic Management Journal, 33(1), 88-106.

Zott, C., \& Amit, R. (2013). The business model: A theoretically anchored robust construct for strategic analysis. Strategic Organization, 11(4), 403-411.

Zott, C., Amit, R., \& Massa, L. (2011). The business model: Recent developments and future research. Journal of Management, 37(4), 1019-1042. 